UDC: $811.112 .2 ’ 373.7: 371.3$

Ана А. Чабрић-Чича

Гимназија Бања Лука

anacabric@gmail.com

\title{
ОБРАДА ФРАЗЕОЛОГИЗАМА У НАСТАВИ ЊЕМАЧКОГ ЈЕЗИКА ${ }^{1}$
}

\author{
Апстракт
}

Иако фразеологизми представљају незаобилазан саставни дио свакодневне комуникације, често су, када је ријеч о настави страних језика, потпуно запостављени. Поставља се питање шта је узрок тог занемаривања и шта учинити да бисмо то промијенили. У овом раду даје се преглед одговора на три основна питања у фразеодидактици: зашто поучавати фразеологизме, шта тачно поучавати, те како их поучавати. С обзиром на особине по којима се фразеологизми разликују од осталих лексема које се обрађују на часу, њиховој обради морамо приступити на другачији начин. Посебна пажња посвећена је питању како поучавати фразеологизме у настави. Полазећи од Киновог ${ }^{2}$ фразеолошког трокорака (препознати, разумјети и употријебити фразеологизам) конструисан је приједлог за обраду фразеологизама и дати су примјери вјежби које су лако примјењиве за обраду фразеологизама и у другим контекстима.

Кључне ријечи: фразеологизам, фразеодидактика, фразеолошки трокорак.

\section{1. УВОД}

Питање поучавања фразеологизама је и раније заокупљало пажњу научника, али се тек деведесетих година прошлог вијека појављују радови који се баве овом тематиком. Захваљујући њима, фразеодидактика се постепено

1 Овај рад дио је ширег истраживања у оквиру мастер рада Заступљеност фразеологизама у уцбеницима и могућности њихове примјене, одбрањене на Филозофском факултету у Новом Саду под менторством проф. др Иштвана Богнера.

2 Петер Кин (Peter Kühn), њемачки лингвиста, професор на Универзитету у Триру. Значајан по својим радовима на пољу фразеологије и фразеодидактике. 
буди из „трноружичиног сна““3 и издваја као посебна грана фразеологије која се бави поучавањем фразеологизама у настави како матерњег тако и страног језика. Када је ријеч о настави страних језика, углавном су пажњу научника заокупљала питања зашто и како поучавати фразеологизме, те да ли постоји фразеолошки минимум или оптимум. Конкретни одговори на ова питања, „магични рецепт“ за бољу наставу не постоји, али постоје одређени приједлози који нам могу олакшати њихову наставну обраду. Узрок непостојања конкретних одговора скрива се највише у самим фразеологизмима и посљедица је њихових специфичности.

\section{1. ФРАЗЕОЛОШКЕ ОСОБИНЕ КАО УЗРОК ПРОБЛЕМА ПОУЧАВАЬА ФРАЗЕОЛОГИЗАМА}

Ако желимо да обрађујемо фразеологизме у настави, прво морамо објаснити ученицима шта је то у ствари фразеологизам. Одговор на ово питање није лако дати. Већ сам термин фразеологизам (њем. Phraseologismus) није општеприхваћен. У њемачкој литератури поред овог термина који је данас, чини се, најраспрострањенији, наилазимо и на друге термине старијег датума настанка. Тако код Пилца (наведено у Palm 1997) сусрећемо термин Phraseolexem, а код Клапенбаха (Исто) термин Phrasem. Бургер првобитно користи термин phraseologische Ganzheit, међутим, временом закључује да тај термин није у потпуности прикладан, те почиње да користи термин Phraseologismus (Burger 1998). У домаћој литератури користе се изрази: идиом, фразем, устаљена фраза, идиоматска фраза (Мршевић-Радовић 1987, наведено у Лазаревић 2007). Сљедећа ставка која у науци изазива многе полемике јесте њихова дефиниција. Мишљења научника се разилазе када су у питању пословице, крилатице, стручни термини, устаљени глаголски спојеви и њихов статус у оквиру фразеологије, односно питања да ли их третирати као фразеологизме или не. Посљедица непостојања општеприхваћене дефиниције је и непостојање јасне класификације. Иако су се деценијама многи научници бавили овом проблематиком, нису успјели пронаћи рјешење које би било прихватљиво за све. ${ }^{4}$

На основу анализе одређеног броја постојећих дефиниција сложићемо се са ауторима који фразеологизме дефинишу као стабилне спојеве ријечи различите синтаксичке структуре са мање или више израженом идиоматичношћу (уп. Burger 1998; Fleischer 1982; Palm 1997). Чињеница је да су у овој дефиницији садржане особине, односно критеријуми који нам помажу да

3 Термин користи Петер Кин (1987: 881).

4 Више о питању класификације њемачких фразеологизама види Флајшер (1982: 116ff), Бургер (1998: 33ff). 
идентификујемо фразеологизам у контексту, а то је један од предуслова за поучавање фразеологизама у настави.

Израз „спојеви ријечи“ (из претходно усвојене дефиниције) указује на особину вишечланости. Минимална структура фразеологизма састоји се од двије ријечи. По Флајшеру (1982: 34), то је спој аутосемантичке ријечи (именице, глаголи, придјеви, прилози и бројеви) и синсемантичке ријечи (замјенице, приједлози, везници и чланови), нпр. auf Dauer („дугорочно“5). По Бургеру (1998: 16) није битно да ли се ради о аутосемантичким или синсемантичким ријечима, па се тако у фразеологизме убрајају и изрази типа vor allem („првенствено“). Што се тиче максималне структуре, не постоји граница, постоје чак фразеологизми који садрже и до седам аутосемантика, али ту се углавном ради о фразеологизмима у ширем смислу ријечи (пословице, крилатице, велеризми), нпр. Gibt man dem Teufel den kleinen Finger, so nimmt er die ganze Hand (даш некоме прст, а он ти узме ичијелу руку) (Palm 1997: 42).

Учење фразеологизама отежава и чињеница да фразеологизми имају чврсту структуру и да углавном не дозвољавају морфолошке и синтактичке операције. То је посљедица другог критеријума - стабилности. Стабилност утиче и на то да се компоненте у оквиру фразеологизма не могу замијенити другим синонимним изразима, иако понекад постоји више варијанти истог фразеологизма, нпр. jeden Pfenning (dreimal) umdrehen (сваки динар трипут обрнути), keine Ruhe geben (lassen) („не дати мира“) и др. (Palm 1997: 29). Стабилност је и узрок трансформационе дефективности - то значи да фразеологизме не можемо подвргнути трансформацијама које су уобичајене за слободне спојеве ријечи. ${ }^{6}$

Критеријум идиоматичности односи се на степен семантичке трансформације кроз коју пролазе компоненте у оквиру фразеологизма. Тако Палм (1997: 12) сматра да фразеологизам може бити:

- потпуно идиоматизован, нпр. etwas (mit) in Kauf nehmen (,пристати на компромис“") - у овом фразеологизму све компоненте су семантички трансформисане;

- дјеломично идиоматизован, нпр. sich ins Fäustchen lachen (,потајно се смијати“) - глагол смијати се није трансформисан;

- постоје и фразеологизми који нису идиоматизовани, тј. ниједна њихова компонента није семантички трансформисана, нпр. sich die Zähne putzen (,„прати зубе“").

5 Превод фразеологизама је наш.

6 Детаљније Флајшер (1982: 54-63). 
Фразеологизми се не могу једноставно изједначити са својим нефразеолошким еквивалентима јер је у њима садржана још једна додатна процјена чињеница од стране говорника, а то је посљедица њихове семантичке вишезначности. Флајшер (1982: 183) као примјер наводи фразеологизам jm das Fell über die Ohren ziehen (,искористити, преварити некога“), који је, иако по значењу близак фразеологизму jn auf den Arm nehmen (,насамарити некога“), семантички гледано, интензивнији од њега. Ова чињеница доводи до тога да ученици често, недовољно познавајући фразеологизам, исти употријебе у неадекватном контексту.

Познавање ових особина ученицима олакшава препознавање фразеологизма и представља први корак при обради фразеологизама. ${ }^{7}$

\section{2. ПРЕГЛЕД ОСНОВНИХ ФРАЗЕОДИДАКТИЧКИХ ПИТАЮА}

\section{1. ЗАШТО ОБРАЪИВАТИ ФРАЗЕОЛОГИЗМЕ У НАСТАВИ?}

Након уочених особина фразаеологизама, очигледно је да их не можемо у потпуности изједначити са осталим лексемама које обрађујемо на часу. Поставља се питање да ли уопште обрађивати фразеологизме у настави и како. Они захтијевају један другачији дидактички приступ и често представљају „камен спотицања“ за некога ко учи страни језик (Lüger 1997: 76). Одговор је дефинитивно потврдан, а покушаћемо да образложимо зашто.

Подучавати страни језик значи много више од пуке обраде граматичких структура и одређеног фонда ријечи. Основни циљ наставе је стицање комуникативне компетенције. Ученике је потребно оспособити да језик употребљавају у реалним ситуацијама. Већина савремених уџбеника за учење страних језика садржи велики број аутентичних текстова ради тог циља. Без обзира да ли се ради о новинском чланку, разговору, интервјуу, стрипу или цртаном филму, фразеологизми су присутни у свакодневној комуникацији и немогуће их је заобићи. Човјек помоћу њих покушава да вербализује своје емоције, ставове, понашање и да их презентује на најефикаснији начин (Palm 1997: 1). Истраживања су показала да дјеца фразеологизме матерњег

7 Поред ових критеријума, у литератури наилазимо и на критеријуме лексикализације и репродукиије. Лексикализација подразумијева прихватање и похрањивање фразеологизма у рјечник, а термин репродукција да фразеологизми постоје као готови инстант изрази који нам стоје на располагању и не морамо их сваки пут поново формулисати, што нама, као страним говорницима, може бити од значајне помоћи, али само под условом да овладамо правилима њихове употребе (Palm 1997: 36). 
језика усвајају паралелно са другим лексемама, као и да степен когнитивног развоја и старост дјетета не играју никакву улогу (Häcki Buhofer 1997: 211).

Чему онда одлагати обраду фразеологизама и у настави страних језика? Сложићемо се са оним научницима (уп. Häcki Buhofer 1997, Hessky 1997, Jesenšek 2006) који тврде да фразеологизми морају бити заступљени од самог почетка учења страног језика и да не постоји никакав оправдан разлог да се успорава учење и обрада фразеологизама док ученици не савладају основе страног језика. То, наравно, не значи да је потребно од самог почетка учења језика одвајати часове посвећене обради фразеологизама, већ да би требало, испочетка, скренути пажњу на њих онда када се појаве у тексту.

Чињеница је да су фразеологизми захтјевни за обраду на часу, али сви већ наведени разлози указују на то да су и незаобилазни ако желимо да постигнемо основни циљ наставе страних језика, а то је комуникативна компетенција.

\section{2. ШТА ТАЧНО ПОУЧАВАТИ?}

Још једно питање којим се баве фразеолози је питање фразеолошког минимума или оптимума. ${ }^{8}$ Постоје одређена истраживања чији су резултат листе фразеологизама, а базирана су на различитим критеријумима од којих се најчешће помињу употребљивост и фреквентност. Халштајндотир, Шајанкова и Квастхоф су (2006:124ff), ослањајући се на резултате својих ранијих истраживања фреквентности и познавања фразеологизма од стране говорника матерњег језика, дошли до закључка да постоји веза између њих. Што је фразеологизам фреквентнији, то га и говорник матерњег језика чешће употребљава. Они су саставили листу са 143 фразеологизма који би требало да се посматрају као отворено језгро језичког оптимума и да буду обрађивани у оквирима $\mathrm{DaF}$ наставе. Поред ове групе, дали су преглед фразеологизама којима би требало да владају ученици на вишим нивоима учења, као и оне који би требало да представљају дио пасивне фразеолошке компетенције. ${ }^{9}$

Овакве листе нам могу бити од помоћи, посебно ако желимо да сами осмислимо радне листове које ћемо употребљавати у настави или тражимо одговарајуће текстове. Приликом планирања часа би требало водити рачуна и о нивоу учења (A1-C2), циљу учења (туристичка посјета, студирање, пословни контакти), типу текста (лично писмо, извјештај, новински чланак), те контрастивност матерњег и страног језика (уп. Hessky 1992: 167). Када ка-

8 Термин оптимум сусрећемо код Хески (1992: 167).

9 Комплетна листа се може пронаћи на страници: http://www.linguistik-online.de/27_06/ hallsteinsdottir_et_al.html 
жемо контрастивност, мислимо на подударање њемачких фразеологизама и њихових еквивалената у нашем језику. Најлакше је обрадити фразеологизме код којих постоји потпуно подударање како у форми тако и у значењу. Тако he, на пример, ученици веома лако препознати фразеологизам jm aus der Hand fressen (jести некоме из руке) и без помоћи наставника открити његово значење. Међутим, ако не постоји подударање у форми са еквивалентом у матерњем језику, као што је случај са фразеологизмом jm den Kopf waschen и његовим еквивалентом у нашем језику очитати некоме буквицу који се потпуно разликују у форми, ученицима ће бити потребна помоћ наставника да открију његово значење, а потом су неопходне вјежбе да би га употријебили у одговарајућем контексту што захтијева додатну припрему.

У потрази за одговором шта тачно поучавати, може нам помоћи и EPHRAS. Ради се о фразеодидактичком материјалу који можемо пронаћи на CD/ROM-y и на интернету, а који је настао као резултат EPHRAS пројекта на ком су радила четири универзитета из четири земље: Универзитет Марибор (Словенија), Карел-Франценс универзитет Грац и Технички универзитет Грац (Аустрија), Универзитет Печуј (Мађарска) и Универзитет Свети Ћирило и Методије Трнава (Словачка) у периоду од октобра 2004. до септембра 2006. (Краљ/Кацјан 2011). EPHRAS је вишејезична фразеолошка база података са више од 4.000 фразеологизама, а ту је и 600 интерактивних вјежби диференцираних по нивоима Заједничког европског референтног оквира за језике, и то од нивоа В1 до С1.

У бази се налазе фразеологизми који су резултат истраживања употребе фразеологизама које је извршила Шајанкова (2005). Истраживала је познавање и употребу фразеологизама од стране матерњих говорника. Коришћени су фразеологизми који се налазе у рјечницима за њемачки као страни језик, а говорници су испуњавали анкету (Hallsteinsdottir 2011). Анкета се састојала од 1.179 фразеологизама, а испитаници су износили свој лични став о њима. Издвојила су се 242 фразеологизма (Šajánková 2005).

За сваки издвојени фразеологизам дат је преглед најважнијих информација у вези са њиховом репродукцијом и продукцијом. Потом слиједе вјежбе израђене по посебној типологији развијеној за овај пројекат, а подијељене по језицима, темама, нивоима и вјештинама. Фразеолошки трокорак, о ком ће у наставку бити више ријечи, проширен је фазом утврђивања, тако да се дидактички концепт састоји од четири фазе (препознати фразеологизам, закључити његово значење, утврдити и употријебити га) (уп. Краљ/Кацјан 2011). 
Фразеологизми у вјежбама груписани су по темама: 19 тема са по пет фразеологизама по теми, што наставнику може знатно олакшати припрему часа. ${ }^{10}$

Које фразеологизме обрадити на часу, зависи од тема и текстова који се обрађују. Требало би их обрађивати онда када се појаве у тексту, а не изоловано.

\section{3. КАКО ПОУЧАВАТИ ФРАЗЕОЛОГИЗМЕ?}

Иако фразеологизми захтијевају један другачији дидактички приступ у односу на друге лексеме који се обрађују у настави, није их потребно засебно обрађивати и поготово не изоловано. Већина аутора се слаже да би полазна тачка требало да буду текстови (уп. Bergerová 2011; Hallsteinsdóttir 2011). Као посебно „захвалне за обраду“ Бергерова (2011) истиче краће текстове као што су: новински наслови, хороскопи, вицеви, афоризми, рекламе, цитати. Халштајндотир (2011) нам показује како се њемачка музика може искористити за обраду фразеологизама и наводи пјесме Петера Фокса (Peter Fox), Јоханеса Кирхберга (Johannes Kirchberg) и групе Принцен (Prinzen). Наводи и примјере како се ове пјесме могу уклопити у теме које се обрађују на настави (нпр. породица, везе, околина, превозна средства и сл.), те могу послужити и као вјежба слушања и/или основа за дискусије. Ако се ради о млађим ученицима, фразеологизме је најбоље обрађивати кроз игру, уз помоћ дијалога и драмских улога, како би их несвјесно усвојили и почели употребљавати. Ако се, међутим, ради о старијим ученицима или одраслима, било би добро, у тренутку када се у неком тексту појави фразеологизам, одвојити мало времена и истаћи да је ријеч о фразеологизму. Уз помоћ фразеологизма илуструјемо ученицима како функционише језик, будимо у њима свијест о томе како могу користити фразеологизме у свакодневној комуникацији и односима са другим људима, али и културама. Ако се ради о неком напреднијем нивоу учења, требало би поучити ученике како да препознају фразеологизам и убудуће. Наиме, веома је важно оспособити ученика да развије стратегије којима би касније самостално могао закључити значење фразеологизма и анализирати га (Lüger 1997: 115). Етингер (1997: 899) сматра да би, у ту сврху, требало направити радни лист који би, између осталог, садржао опис фразема на страном језику, објашњење појединих ријечи, напомене везане за етимологију, парафразе у матерњем језику, односно одговарајући еквивалент, потом тачан и детаљан опис услова коришћења, те евентуалне напомену о стилу, фреквентности и гестикулацији, а Лугер (1997: 95-96) даје

10 Демо верзија EPHRAS налази се на страници http://demo.ephras.org/. 
примјер како би такав радни лист могао изгледати. За израду оваквог радног листа потребно је много времена и висок ниво познавања језика. Поменути радни листови могу олакшати учење студентима, али нису у складу са наставним циљевима у школама. Ученици би требало да буду оспособљени да одређене фразеологизме користе у комуникацији, али не и да се баве детаљном анализом фразеологизама.

\subsection{1. Фразеолошки трокорак}

Једно од значајнијих имена, када је фразеодидактика у питању, јесте Петер Кин (Peter Kühn). Многи фразеодидактички приступи данас базирају се на његовом фразеолошком трокораку. Кин (1996: 16) наводи практична правила за обраду фразеологизама:

1. Не вјерујте у бајку о основном инвентару често употребљаваних фразеологизама. До сада не постоје научно доказане спознаје о фреквентности фразеологизама.

2. Избјегавајте појединачне часове везане за фразеологизме. Обрађујте их тамо гдје се појављују у аутентичној комуникацији. Консеквентно се придржавајте овог принцпа: уз помоћ типова текстова, тема, ситуација и контекста формираће се само од себе листа „важнијих“, „типичнијих“ или „учесталијих" фразеологизама.

3. Не приписујте фразеологизме одређеном регистру. Они се стилски могу употријебити на много начина: у писаном и говорном језику, као и у приватним, полујавним и јавним пригодама.

4. Поштујте фразеолошки трокорак. Ученици би требало да фразеологизме препознају, разумију и употријебе. Вјежбајте препознавање и разумијевање фразеологизама на текстовима. Мислите на то да DaF ученици фразеологизме могу употријебити само када су упознати са типом текста, адресатом и ситуацијом. Посебну пажњу поклоните употреби фразеологизама у разговорима у разреду.

5. Усвојите правило: рад са фразеологизмима је рад са текстовима и на текстовима. Фразеологизми се употребљавају везано за одређен тип текста, одређеног адресата и у складу са ситуацијом. Овај начин употребе мора бити разрађен.

6. Водите рачуна о семантичкој вишезначности фразеологизама. Покушајте ову вишезначност истакнути уз помоћ контекста.

О првом Киновом правилу може се дискутовати. Споменута истраживања која су спровели Шајанкова (2005), те Халштајндотир, Шајанкова и Квастхоф (2006: 124ff) довела су до научних спознаја о фреквентности фразеологизама које оповргавају ово правило. 
Најзанимљивије је четврто правило које представља конкретан одговор на питање како поучавати фразеологизме, то је, у ствари, дидактички поступак за практично усвајање фразеологизама тзв. фразеолошки трокорак (Кühn 1992: 177ff). Овај поступак представља основу за четири корака (препознати, разумијети, утврдити и употријебити фразеологизам) који данас важе за основне фазе при усвајању фразеологизама (Ettinger 2007). С обзиром да дидактички концепт фразеолошког трокорака игра важну улогу при настанку и развоју наставних материјала (уп. Hallsteinsdóttir 2011), у наставку ћемо детаљније објаснити сваки корак.

1. Први корак представља препознавање фразеологизма. Да би ученици били у стању да препознају фразеологизам, требало би им, као што је већ речено, скренути пажњу на фразеолошке особине, њихову специфичну структуру и могућност постојања одређених морфо-синтактичких аномалија попут одређених граматичких структура и конструкција које се више не употребљавају. Палм (1997: 31) наводи, као примјер, недеклинирани придјев у атрибутивној употреби sich bei jm lieb Kind machen („умиљавати се некоме“) или атрибутивни генитив на првом мјесту des Pudels Kern sein (у том грму лежи зеи). Поред ових морфо-синтактичких аномалија, ту су и семантичко-синтаксичке инкомпатибилности. У случају слободних лексема често можемо открити значење цијелог израза из контекста. Код фразеологизама то често није могуће због њихове идиоматичности. Кин (1992: 179) ову разлику илуструје примјерима:

Peter und Irmgard sitzen auf den Stühlen. („Петар и Ирмгард сједе на столицама“) / Peter und Irmgard sitzen auf den Ohren. („,Петар и Ирмгард сједе на ушима").

У првој реченици глагол sitzen је, уз помоћ приједлога, везан за прилошку одредбу за мјесто, а значење реченице представља збир значења појединачних лексема. У другој реченици присутан је исти приједлог, ту је и прилошка одредба за мјесто, ученик познаје значење свих лексема, али и поред тога реченица звучи нелогично. Управо то је сигнал да се ради о фразеологизму. Очигледно је да у овом другом случају значење реченице није збир значења појединих ријечи, већ представља цјелину чије се значење разликује од значења њених компоненти (Palm 1997: 9). Матерњи говорник неће имати проблема са разумијевањем ове реченице, али неко ко је тек почео да учи њемачки језик, или зна само основе, тешко да ће, без проблема, схватити значење овог израза, посебно ако у његовом матерњем језику не 
постоји сличан израз. Још један приједлог за препознавање фразеологизма јесте контекстуална сензибилизација уз помоћ вицева чија су окосница неспоразуми у комуникацији, на примјер: Zahnarzt zu einem kleinen Patienten: „, So, jetzt wird nicht mehr geweint. Mach mal den Mund schön weit auf und beiß die Zähne zusammen "1l (Wotjak 1996: 8; Lüger 1997: 105).

2. Сљедећи корак представља разумијевање фразеологизма. Потребно је ученику објаснити значење фразеологизма, али и настојати да га он разумије. Кин и за овај корак наводи одређене поступке. Први је објашњење уз помоћ слике за који истиче да није прикладан за $\mathrm{DaF}$ ученике из два разлога. Прво, ученици би могли погрешно да протумаче значење због сличне или потпуно различите слике коју тај фразеологизам има у матерњем језику ученика. Овај поступак би требало ограничити на фразеологизме за које постоје еквиваленти у нашем језику који се потпуно или дјелимично подударају у форми и значењу са њемачким. Ученици ће, на примјер, схватити значење фразеологизма das Geld aus dem Fenster werfen (бацати новац кроз прозор) ако им покажемо слику неке особе која баца новчанице кроз прозор. Међутим, ако им за фразеологизам die Tapeten wechseln (,промијенити мјесто боравка, преселити се“) покажемо слику особе која мијења тапете у стану, нећемо им помоћи да закључе које је његово значење. Други разлог јесте то што се велики број фразеологизама не може приказати сликом нпр. nicht wahr? (,,зар не?“), ab und $z и($, ,у и тамо“).

Ученици би могли да користе рјечник да би разумјели значење фразеологизма. За њемачке фразеологизме и њихове еквиваленте у нашем језику можемо користити „Немачко-српскохрватски фразеолочки рјечник. Немачки идиоматски израз с юеговим српскохрватским еквивалентима" Павице Мразовић и Ружице Приморац (1981). Етингер (2007) доказује да и овај поступак има своје недостатке. Истиче да за већину језика не постоје одговарајући рјечници, а осим тога, тумачења су често непотпуна и не покривају ни најбитније контексте у којима се одређени фразеологизам може појавити или се, до крајности, покушава навести што већи број еквивалената. Често се деси да еквивалент није ништа друго до једна од могућности превода фразеологизама, те стога не можемо бити сигурни да је ученик заиста разумио значење фразеологизма у датом конексту.

11 Зубар малом пацијенту: „Нема више плакања. Отвори фино широм уста и стисни зубе.“ (Превод је наш). 
3. Трећи и најзахтјевнији корак јесте употреба фразеологизама. При употреби морамо водити рачуна о адресату, ситуацији и типу текста, тј. контексту што итекако може представљати проблем за некога ко учи страни језик и проузроковати непријатне ситуације. Често се, иако добро владамо страним језиком, дешава да употријебимо фразеологизам у погрешном контексту. Разлог је прагматична вишезначност, односно правила употребе фразеологизама. Поставља се питање, ко, када, у ком контексту, може употријебити одређени фразеологизам, а да не направи прагматичну грешку. Може се десити да је употријебљени фразеологизам застарио, регионално се не употребљава, да не одговара датом типу текста, да није прикладан у датој ситуацији (Lüger 1997; Bergerova 2005).

Кин предлаже да се, након другог корака, покуша са фазом утврђивања када би ученик обрађивао исти фразеологизам у другим текстовима и контекстима. Након ове фазе би слиједила провјера. Лигер, с друге стране, сматра да би утврђивању требало поклонити много више пажње и да би оно требало да представља засебан четврти корак, који би услиједио након фазе разумијевања (1997: 101).

\subsection{2. Примјер обраде фразеологизама у настави}

Фразеолошки трокорак према Етингеру (2007) представља основу за четири корака (препознати, разумијети, утврдити и употријебити фразеологизам) који данас важе за основне фазе усвајања фразеологизама. На конкретном примјеру илустроваћемо ова четири корака. За постизање оптималних резултата предлажемо да се посебна пажња посвети вјежбању, као и да се, посебно ако се први пут обрађују фразеологизми, узме у обзир и фаза сензибилизације, која претходи првом кораку. Наиме, прије вјежбања, ученике би требало упознати са фразеологизмима како би развили способност препознавања фразеолошких особина.

Лигер предлаже примјену методе учења по станицама. Ученици се подијеле у групе, свака група има на располагању 5-10 минута да анализира један дио материјала. ${ }^{12}$ Затим би требало да се замијене док све групе не обраде све задатке, потом слиједи пленумска дискусија. Што се текстова тиче, предлаже краће рекламне текстове или монтажу новинских наслова, а у обзир долазе и карикатуре, фотографије, цртежи и вицеви (1997: 102).

Још један приједлог за фазу сензибилизације јесте да се ученицима покажу илустрације на којима су представљени фразеологизми. Ученици 12 Под материјалом овдје подразумијевамо одређени тип текста. 
погађају шта оне, у ствари, представљају. Потом се ученицима дају фразеологизми са задатком повезивања фразеологизама са сликама. Као сљедећи корак Гундогду (2007) предлаже да ученици у групама покушају пронаћи еквиваленте у матерњем језику. Дорнбуш (1996: 40) томе додаје и парафразе који би ученици требало да повежу са фразеологизмима.

Послије фазе сензибилизације слиједи први корак, а то је препознавање фразеологизама. Ученицима се могу дати различити типови текстова попут новинских чланака, писама читалаца, реклама. У наставку рада ћемо, на примјеру из праксе, дати приједлог за обраду фразеологизама у настави.

Час је одржан са ученицима трећег разреда гимназије, а као материјал послужила је пјесма „Freundschaften““ („Пријатељства“) Ханса Манца. ${ }^{13}$

\author{
"Freundschaften" \\ „Könntest du notfalls \\ das letzte Hemd vom Leib weggeben, \\ dich eher in Stücke reißen lassen, \\ als ein Geheimnis verraten? \\ Lieber schwarz werden, \\ alsjemanden im Stich lassen? \\ Pferde steblen oder durchs Feuer gehen?" \\ $\square$ "Ja." \\ ${ }_{10} \square$ "Auch für mich?“ \\ $\square$ "Ja." \\ „Dann bist du mein Freund."
}

Hans Manz

notfalls $\approx$ im Falle, dass es wirklich notwendig sein sollte

Слика 1. „Freundschaften“ Ханс Манц (deutsch.com 3: 96)

Након што су ученици прочитали пјесму и урадили задатке за опште разумијевање, добили су задатак да пронађу фразеологизме у њима. Потом су цртежом представили пронађене фразеологизме. Метод визуализације ученицима помаже да боље меморишу фразеологизам. Цртеж у наставку јесте рад ученика настао након обраде ове пјесме. Представљени су фразеологизми: das letzte Hemd vom Leib weggeben (дати за некога задюу кап крви), für jm durchs Feuer gehen (ићи кроз ватру за некога), schwarz werden („умријети“), jm im Stich lassen (оставити некога на иједилу), mit jm Pferde stehlen könпеп (моћи с неким коње красти).

13 Пјесма се налази у уџбенику deutsch.com 3 издавачке куће Hueber. 


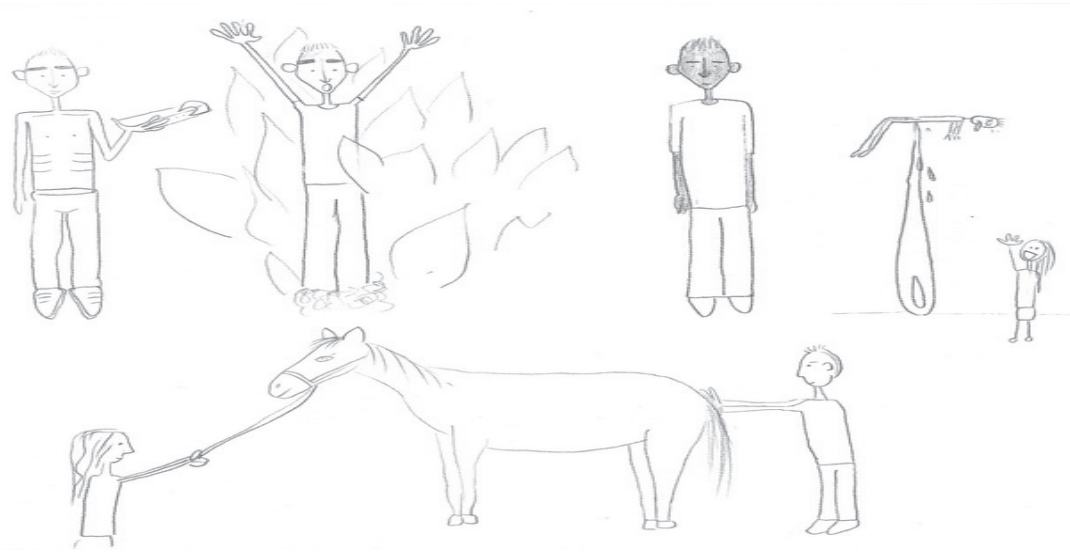

Слика 2. Илустрација фразеологизама из пјесме ${ }^{14}$

Након ове фазе, ученици су добили радни лист са конкретним структурним вјежбама са задатком да подвуку и/или допуне одговарајућом ријечи:

1. Was passt nicht? Streiche.

1. das letzte Hemd/T-Shirt vom Leib weggeben

2. für jm durchs Feuer/Flamme gehen

3. schwarz/rosa werden

4. jm im Stich führen/lassen

5. mit jm Pferde/Schafe stehlen können

2. Ergänze die fehlenden Wörter!

1. das letzte. vom Leib weggeben

2. für jm durchs gehen

3. .................werden

4. jm im Stich

5. mit jm. stehlen können

Да бисмо увјежбали структуру фразеологизма, користимо вјежбе репродуктивног карактера које имају за циљ меморисање израза. Учесталим понављањем губи се повезаност са реалним ситуацијама, међутим, чињеница је да само тако можемо учврстити нову структуру.

Није довољно да ученици савладају само форму фразеологизма, потребно је и да разумију његово значење да би могли адекватно да га упот-

14 Илустрације су рад ученице Н. Нинковић. 
ријебе. За провјеру (да ли су ученици схватили значење фразеологизма) користили смо два низа израза. У првом низу су се налазили фразеологизми, а у другом објашњење њиховог значења. Задатак је био да их повежу: ${ }^{15}$

3. Was passt? Verbinde.
1. das letzte Hemd vom Leib weggeben
a) jm in einer Notlage allein lassen

2. für jm durchs Feuer gehen b) mit jm Außergewöhnliches unternehmen können

3. schwarz/werdenc) das Letzte für jn opfern, um ihm zu helfen

4. jm im Stich lassen d) bereit sein für jn alles zu tun

5. mit jm Pferde stehlen könnene)hier: sterben

Вјежбе повезивања могу да се комбинују са неким визуелним приказом, те тако можемо ученицима припремити и игру меморије гдје би добили задатак да повежу фразеологизам са одговарајућом сликом (Dornbusch et al. 1996: 37).

Сљедећи корак је контекстуализација. Ученици би требало да фразеологизам, чију су форму и значење већ упознали, употребе у одговарајућем контексту:

4. Ergänze den passenden Ausdruck.

1. „Mein Bruder bedeutet mir alles. Für ihn würde ich sogar

2. „Peters Eltern haben sich während seiner Krankheit für ihn aufgeopfert. Sie waren bereit , um ihm zu helfen "

3. „Maria ist nicht mehr meine beste Freundin. Sie hat , als ich sie gebraucht habe."

4. „Auf meine beste Freundin kann ich mich 100 Prozent verlassen. Ich mit ihr

Последњу групу чине вјежбе у којима се фразеологизми продуктивно употребљавају. Ученици су, у паровима, добили задатак да изаберу један од обрађених фразеологизама и направе дијалог у коме користе тај фразеологизам. Потом су одглумили своје дијалоге. ${ }^{16}$

Овакав дидактички поступак обраде фразеологизама лако се може прилагодити и другим темама и типовима текстова. Прелаз ка продуктивној

15 Вјежба је преузета из уџбеника (deutsch.com 3: 96).

16 Идеје за вјежбе: упореди Ансимова (2002) и Лигер (1997). 
употреби, не само фразеологизама већ и других лексема, представља најтежи корак у учењу страног језика. Прво би требало увјежбати фразеологизме у оквиру познатих ситуација и тек онда, постепено, прелазити на вјежбе отвореног типа, те коначно остварити слободну употребу фразеологизама у непознатим околностима.

\section{ЗАКљУЧАК}

Ако желимо да постигнемо основни циљ наставе страних језика данас, а то је стицање одређеног нивоа комуникативне компетенције, морамо ученике оспособити да овладају и употребом фразеологизама који су незобилазни у свакодневној комуникацији. Стога је потребно да се обради фразеологизама у настави посвети много више пажње. Иако постоје одређена истраживања и конкретне листе фреквентнијих фразеологизама које би требало савладати, у настави је ипак најбоље обрађивати оне фразеологизме који се појављују у текстовима. При обради фразеологизама потребно је поштовати четири корака који данас важе за основне фазе при усвајању фразеологизама, а то су: препознати, разумијети, утврдити и употријебити фразеологизам. Посебна пажња мора се посветити вјежбама које ученицима помажу да савладају форму и схвате значење фразеологизама. Прије саме обраде, посебно ако се први пут обрађују фразеологизми, потребна је и фаза сензибилизације. То ће помоћи ученицима да лакше пронађу фразеологизам у контексту. Прелаз ка продуктивној употреби фразеологизама мора бити поступан и постепен, јер једино тако можемо избјећи њихову неадекватну употребу у свакодневној комуникацији.

\section{ЛИТЕРАТУРА}

Anisimova, E. V. (2002). "Phraseologismen im Unterricht Deutsch als Fremdsprache. Germanistisches Jahrbuch der GUS „Das Wort” 2002“, 245-256. Pristupljeno 19. 3. 2011. http://www.daad.ru/wort/wort2002/ Anisimova.Druck.pdf

Bergerova, H. (2005). "Phraseologievermittlung im DaF-Unterricht? - Auf jeden

Fall! Aber wie?", in Festschrift zum 15. Grundungsjubilaum des Lehrstuhls Germanistik, eds. Bergerova, Cornejo, Haring (Usti nad Labem: UJEP): 57-69.

Bergerova, H. (2011). "Zum Lehren und Lernen von Phraseologismen im DaFStudium. Überlegungen zu Inhalten und Methoden ihrer Vermittlung 
anhand eines Unterrichtsmodells“. Linguistik online 47, 3/11: 107-129. Pristupljeno 8. 5. 2014. https://bop.unibe.ch/linguistik-online/article/ view/358

Burger, H. (1998). Phraseologie: Eine Einfuhrung am Beispiel des Deutschen. Berlin: Erich Schmidt Verlag.

Dornbusch, C. et al. (1996). "Descascar um abacaxi"=eine Ananas schälen?

Zur Didaktik von Phraseologismen im Sprachvergleich (brasilianisches)

Portugiesisch-Deutsch". Fremdsprache Deutsch 15: 4-9.

Ettinger, S. (2007). "Phraseme im Fremdsprachenunterricht", in Phraseologie. Ein internationales Handbuch zeitgenössischer Forschung, eds. Burger, Dobrovol'skij, Kühn Bd. 28.1 и 28.2. (Berlin/New York: Walter de Gruyter): 893-908. EPHRAS (n.d.): http://www.ephras.org/01-1-Kurzbeschreibung. php. Pristupljeno 14. 8. 2014.

Fleischer, W. (1982). Phraseologie der deutschen Gegenwartssprache. Leipzig: VEB Bibliographisches Institut Leipzig.

Gündoğdu, M. (2007). "Die Behandlung der Phraseologismen im Unterricht Deutsch als Fremd- und Zweitsprache“. DaZ 2/2007: 11-18. Pristupljeno 12. 8. 2014. http://publikationen.ub.uni-frankfurt.de/frontdoor/index/index/ docId/24642

Häcki Buhofer, A. (1997). "Phraseologismen im Spracherwerb", in Wortbildung und Phraseologie, eds. Wimmer, Berens (Tübingen: Gunter Narr Verlag): 209-232.

Hallsteinsdóttir, E. (2001). Das Verstehen idiomatischer Phraseologsmen in der Fremdsprache Deutsch. Hamburg: Verlag Dr. Kovač. Pristupljeno 19. 3. 2011. http://www.verlagdrkovac.de/volltexte/3-8300-0435-4.

Hallsteinsdóttir, E., Šajánková, M., Quasthoff, U. (2006). "Phraseologisches Optimum für Deutsch als Fremdsprache. Ein Vorschlag auf der Basis von Frequenz- und Geläufigkeitsuntersuchungen“. Linguistik online 27: 117-136. Pristupljeno 8. 5. 2011. http://www.linguistik-online.de/27_06/ hallsteinsdottir et al.html

Hallsteinsdóttir, E. (2011). "Aktuelle Forschungsfragen der deutschsprachigen Phraseodidaktik“. Linguistik online 47, 3/11: 3-29. Pristupljeno 8. 5. 2014. https://bop.unibe.ch/linguistik-online/article/view/358

Hessky, R. (1992). “Aspekte der Verwendung von Phraseologismen im Unterricht Deutsch als Fremdsprache“. Fremdsprachen lehren und lernen Nr. 21: 159-168.

Kühn, P. (1992). "Phraseodidaktik. Entwicklungen, Probleme und Überlegungen für den Muttersprachenunterricht und den Unterricht DaF". Fremdsprachen Lehren und Lernen Nr. 21: 169-189. 
Kühn, P. (1996). "Redewendungen - nur im Kontext! Kritische Anmerkungen zu Redewendungen in Lehrwerken“. Fremdsprache Deutsch 15: 10-16.

Kralj, N., Kacjan, B. (2011). "Phraseologieunterricht in der Zeit der neueren Lernmedien“. Linguistik online 47, 3/2011. Pristupljeno 12. 8. 2014. http:// www.linguistik-online.de/47_11/kacjanKralj.html

Lazarević, R. (2007). Frazeološke sintagme u italijanskom i srpskom jeziku. Beograd: Filološki fakultet.

Lüger, H. H. (1997). "Anregungen zur Phraseodidaktik“. Beiträge zur Fremdsprachenvermittlung 32: 69-120.

Palm, C. (1997). Phraseologie: Eine Einführung. Tübingen: Gunter Narr Verlag. Šajánková, M. ( 2004). "Phraseme im Fremdsprachenunterricht", in Deutsche Sprache in der Slowakei II. Geschichte, Gegenwart und Didaktik, eds. Ilpo Tapani Piirainen, Jörg Meier (Wien): 203-218.

Wotjak, B. (1996). "Redewendungen und Sprichwörter. Ein Buch mit sieben Siegeln? Einführung in den Themenschwerpunkt". Fremdsprache Deutsch 15: 4-9.

\section{Ana Čabrić-Čiča}

\section{TEACHING PHRASEOLOGISMS IN GERMAN AS A FOREIGN LANGUAGE}

\section{Summary}

Although phraseologisms represent an essential part of everyday communication, they are often, when it comes to teaching foreign languages, completely neglected. We have to ask ourselves what is the cause for that and what we can do to change it. This paper provides an overview of answers to three basic questions of phraseodidactics: why teach phraseologisms, what should we teach and how should we teach them? Phraseologisms differ from other lexemes we teach in class and they have to be taught in a different way. That is why special attention in this paper is devoted to the question of how to teach phraseologisms. The paper contains a proposal for teaching phraseologisms which is based on Kuhn's phraseological three-step model (recognize, understand and use a phraseologism) and it provides examples of exercises that are easily applied to teaching phraseologisms in other contexts.

Key words: phraseologism, phraseodidactics, phraseological three-step model. 